\title{
Chitra and Savitri as epitomes of women empowerment: A study in comparison
}

\author{
Anupamratanshanker Ramashanker Nagar ${ }^{1}$, Ketki Nareshprasad Pandya ${ }^{2}$ \\ ${ }^{1}$ Principal, Dr. Virambhai Rajabhai Godhaniya College, Porbandar (Gujarat) \\ ${ }^{2}$ Visiting Professor, Gurukul Mahila College, Porbandar (Gujarat) \\ Email address: \\ dranupamnagar09@gmail.com (A. R. Nagar)
}

\section{To cite this article:}

Anupamratanshanker Ramashanker Nagar, Ketki Nareshprasad Pandya. Chitra and Savitri as Epitomes of Women Empowerment: A Study in Comparison. International Journal of Literature and Arts. Vol. 1, No. 3, 2013, pp. 47-54. doi: 10.11648/j.ijla.20130103.15

\begin{abstract}
This paper proposes to discuss the conceptual issues related to Women Empowerment as developed in the characters of Chitra and Savitri. Following a brief critique of their human development, both Chitra and Savitri would stand out as fine illustrations (models) of women empowerment particularly in the post-modern context where one more than often discusses women empowerment as an approach to address gender inequality in societies. As stand-out strong models, both Chitra and Savitri, would serve to educate contemporary writers and their Women (W) Empowerment (E) framework would in turn serve to review the current approaches and practices and thereby establish the unlimited and universal application of the re-contextualized Tagorean and Aurobindonian approach to Women Empowerment. The following would be the four sections of the paper: I. Introduction; II. The Chitra and Savitri Legend; III. The comparison between Chitra and Savitri; IV. The Re-contextualization of Chitra and Savitri in terms of Women Empowerment, V. Conclusion.
\end{abstract}

Keywords: Conceptual Issues, Women's Empowerment, Chitra and Savitri as Symbols of Shakti, Illustrations (Models) of Women Empowerment, the Postmodern Context, Gender Inequality, Myths Recontextualized

\section{Introduction}

Rabindranath Tagore's lyrical drama Chitra reminds man that the ultimate truth is to be found not at the physical base but in the steady evolution of the self. The illumination of a young princess' mind lies in the recognition and realization that it is in Truth alone that true happiness resides. Similarly Aurobindo's epic Savitri narrates the story of a young princess who saves the life of her husband from Death and thereby suggests the ulitmate liberation of man from universal Death. Aurobindo therefore writes poetry to enunciate his philosophy in terms of spiritual action and vision. Chitra and Savitri are Upanishadic works in the sense that their principal theme is search for knowledge ('vidya'), that liberates man from ignorance ('avidya'), and that their main stylistic device is the conversation between the human and divine characters.

Evolution thus becomes the watchword of both Aurobindo and Tagore. The awakening of the self or raising the life and existence to a higher level of consciousness (a spiritual form of women empowerment) is one of the parallel themes observed in Chitra and Savitri. Further, the integral transformation of Chitra and Savitri and their inner intuitive development has a much wider connotation to mankind at large. Although there are fundamental differences in terms of the nature of Chitra and Savitri's awareness there is no denying that these legends from the Mahabharata are exquisite examples of the feminine aspect of the Indian Women. Tagore observes that Indian women know that it is their duty to make their life an image of the eternal life, and that love's mission is truly performed when life has a spiritual meaning. Aurobindo too recognizes woman as the symbol of shakti, the creative power and in this context Chitra and Savitri are the highest tribute to women in general and stand tall as illustrious examples of Women Empowerment.

In effect, Tagore and Aurobindo seek to achieve a realization of human unity, universal peace and happiness, based on a spiritual foundation, which ensure the orderly progress and fulfillment of human destiny. Chitra and Savitri are concerned with the consciousness of man and how it, like all other living things, grows according to its own nature. The drama and the epic offer to mankind the spectacle of a rebirth of life in spiritual terms. The heroines 
of Chitra and Savitri extend their level of empowerment by their experiences of life and eventually acquire selfknowledge and self-transcendence. They educate themselves in the self and in otherness by seeing themselves, their false selves, and finally their whole transcendental beings. The action of both Chitra and Savitri is internal and manifesting an uplifting of thought, feeling and sense. The inner mind is the focal point of the two works. Chitra and Savitri also bear witness to selfexpansion and the conscious subjectivity of the modern feminine mind. Their inwardness is intolerant of the otherworldliness and the asceticism of religion on the one hand and the abstraction of philosophy on the other. They rather meditate on the truth of life and the truth of the spirit respectively.

\section{The Chitra and Savitri Legend}

\subsection{The Chitra Legend}

"Manipureshwaram Rajan dharmagyam Chitravahanam
Tasya Chitrangada nama duhita charudarshana",
Chitra is based on the Mahabharata legend of Chitra is based on the Mahabharata legend of
Chitrangada and Arjuna. Arjuna came to Manipur during the course of his wanderings to fulfil a vow of penance. He saw Chitrangada, the beautiful daughter of Chitravahana, the king of the country and was captivated by her charming beauty. He then asked the king for the hand of his daughter in marriage. The king asked him who he was. On learning that he was Arjuna, the Pandava prince, the King told him that one of his ancestors in the kingly line, named Prabhanjana, was childless for quite a long time. In order to obtain a successor he performed severe penances. Lord Shiva who was pleased with his austerities, granted him a boon that he and his successors would each have one child. It so happened that the promised child had invariably been a son. But Chitravahana, was an exception, as he was the first to have only a daughter to continue his race, whom he named as Chitrangada. He, therefore, always treated her as a son and had also made her his successor. The son that would be born to her would continue the race of the king. He demanded from Arjuna that son as the price of the marriage. On this consideration Arjuna could take her in marriage. Arjuna made a pledge to the King that the son born of this union would continue Chitravahana's race and then Arjuna took Chitrangada as his wife. He lived in her father's capital for three years. When a son was born to them, he embraced his wife with warmth, and bidding farewell to her and her father, set out again on his travels.

Tagore's Chitra is based on the Mahabharata. It is a dramatic sermon on the theme of true love. Arjuna, the Pandava prince spurns the princess Chitra, the daughter of the King of Manipur. Later when transformed into a beautiful damsel by a boon from the god of Love and god of Spring she approaches Arjuna again. He is infatuated. But Chitra conquers her unease by boldly revealing the truth about her. The false woman redeems herself as the true mother-to-be. The sensual is transcended in the spiritual, and the union is consecrated at last. Thus, Tagore's Chitra has a compact and neat structure. But much complexity and richness has been lost in the process of translation. His principal characters tend to be symbolic. His setting is invariably non-realistic. His drama firmly rooted in the Indian ethos in its themes and characters and eminently expressive of his deepest convictions in creative terms, is comparable at its best with the modern imaginative drama of W.B. Yeats and Maurice Maeterlinck.

Let us now examine the variations in the original Mahabharata text of Chitra and the re-contextualized Chitra text by Tagore.

\subsection{Variations in Tagore's Chitra}

Like Shakespeare, Kalidas, and Shelley, Tagore deviated from the original story to suit his requirements. The following are the variations that are observed in the text of Tagore from the Mahabharata:

1. The Chitrangada-Arjuna episode in the Mahabharata runs up to 15 verses, (beginning from stanza no. 13 to stanza no. 27), while Tagore's lyrical drama involves nine scenes.

2. In the Mahabharata, Arjuna meets Chitravahana, the King of Manipur, whereas in Tagore's Chitra, Arjuna never encounters the King.

3. In the Mahabharata, Arjuna accidently meets Chitrangada while in Tagore's Chitra, it is Chitra who sees Arjuna accidently.

4. In the Mahabharata, Chitrangada has been depicted as a youthful damsel of exquisite beauty she is Charudarsana and Vararoha, whereas in Tagore's Chitra, Chitra is unattractive and plain. The whole plot of the drama hinges on this point. Had Chitra been a beautiful woman she would not have approached Madana (Eros) and Vasanta (Lycoris) for lending her charm and grace even for a day, so that she might win the heart of Arjuna.

5. In the Mahabharata, Arjuna makes up his mind to have Chitrangada as his wife and therefore he goes to the King and seeks his permission for the hand of Chitrangada, whereas in Tagore's Chitra, Arjuna does not seek her hand in marriage with the permission of her father or any of her guardians.

6. In the Mahabharata, Arjuna lives with Chitrangada in Manipur for three years, while in Tagore's Chitra, Arjuna stays with her for only a year.

7. In the Mahabharata, Chitrangada gives birth to a boychild and Arjuna after having presented the son to the father of Chitrangada, leaves, whereas in Tagore's Chitra, Arjuna is illuminated with revelation after an year and is reminded of his home. Here Chitra offers the last sacrifice at Arjuna's feet (i.e., flowers of incomparable beauty from the garden of heaven and tells Arjuna that she will teach her child to be a second Arjuna).

8. In the Mahabharata, Chitrangada is observed as a 
submissive daughter and wife. She accepts anything and everything, while in Tagore's Chitra, Chitra is a strong-willed daughter and a fierce individual.

Having studied the Chitra legend in both the original and the reinterpreted mode let us now examine the Savitri legend in both the modes.

\subsection{The Savitri Legend}

"Savitrya preetaya datta Savitrya hutaya hyapi Savitrityeva namasyaschakrurvipraastatha pita."10

Savitri is based on the Mahabharata legend of Savitri and Satyavan. Aswapathi, the king of the Madra kingdom was a popular king, but his one worry was that he had no child. So he performed austerities for eighteen years. The goddess Savitri, then appeared and vouchsafed the boon of a daughter of great beauty.

As prophesized by the goddess, the queen gave birth to a female child before the end of the year. The child was named Savitri, who grew up to be an intelligent, courageous and beautiful girl, loved by all in the kingdom.

The king then told Savitri to choose her life partner, a prince who would be worthy of her. In obedience with the royal command, Savitri travelled with an escort, visiting many countries, till finally she chose Prince Satyavan who was living in a forest hermitage with his father, the blind king Dyumathsena of the Shalwas and mother Shaibya who had lost their kingdom.

Savitri returned home, jubilant and satisfied with her choice. She found her father with the famous sage Narada, who immediately asked her who she had chosen for her husband. When Narada heard that Satyavan was her choice, he begged Savitri to reconsider her decision, as he knew that Satyavan had only one more year to live. But she was determined to marry Satyavan, with whom she was already deeply in love. And so, ignoring the pleas and appeals of her family, she married Satyavan at Dyumathsena's hermitage in a simple ceremony. Savitri and Satyavan went round the sacred fire hand in hand as the priests chanted Vedic mantras.

Savitri and Satyavan loved each other, and were happy together. However, she carried a heavy heart, as she could not forget the prophecy regarding Satyavan's life. Time flew by. Savitri realised that Satyavan's death was approaching. Four days prior to the prophesized end of Satyavan, Savitri undertook a Tri-Ratra vow. On the day marked for Satyavan's death, he set out to the woods with an axe upon his shoulders as usual. Savitri begged him to allow her to accompany him, and with the permission of the in-laws they walked into the forest.

As he was chopping wood, Satyavan felt some pain. He rested his head on Savitri's lap and fell into a slumber. Nearby, a dark shadowy figure emerged, carrying a noose in his hand. He was Yama, the god of Death. Masking her fear of the god, Savitri pleaded with him not to take her husband from her, but Yama refused to listen and started carrying Satyavan away. Savitri followed, persistent and unyielding, as Yama traversed through the forests with
Satyavan on his shoulder. Savitri pleased him with her discourse and purity of heart. Yama then told her to ask for any boon except for her husband's life.

Being wise, Savitri immediately asked that her father-inlaw's eyesight should be restored. The boon was granted, but Savitri did not leave. Yama then granted her three more boons. As a second boon, Savitri asked for the restoration of Dyumathsena's kingdom. This was granted. Her third boon demanded that her own father be blessed with a hundred sons. This too was granted. As the fourth boon, she asked that she herself should bear a hundred sons. Yama granted this boon too, not recognizing the predicament he was to face. Savitri smiled, pointing out to Yama that she could not have a hundred sons without her husband being restored to life. Realising that he had been outwitted, Yama released the soul of Satyavan from his noose.

Savitri returned to the place where Satyavan's body lay. She took his head on her lap, and within a moment, Satyavan regained his life. The couple then proceeded back to Dyumathsena. Concluding his narrative, Rishi Markandeya said:

"Even thus did Savitri redeem from peril and raise to high fortune herself, her father and mother, her father-inlaw, as also the whole race of her husband."11

Thus, the Mahabharata is also the source of Aurobindo's Savitri. Aurobindo has taken 'the Savitri-Satyavan episode' from the Mahabharata and has treated it in his own style in order to fulfil his aim which he has discussed in his 'The Life Divine' (a vast philosophical prose epic) - the issue between threatening Death and the hope of New Life - a marvellous future possibility, is presented in terms of poetry.

\subsection{Variations in Savitri}

The following are the deviations that are observed in the text of Aurobindo from the Mahabharata:

(i) In the legend, the character of Ashwapathy is described only in seven verses. He is said to have resorted to austerities for the personal gain of getting a child. But in Savitri, Aurobindo elaborates the character of Ashwapathy in about twenty-three Cantos. He practices yoga not only for his own self-perfection but also for finding a way for man's liberation.

(ii) In the legend, the whole period of Aswapathy's tapasya as reported has been transformed by the poet into an epic climb of the human soul in its journey from the inconscient to the very gates of the Superconscient.

(iii) In the legend, Savitri is said to be a gift of Goddess Savitri. But in the epic, the Divine Mother accepts the prayer of Ashwapathy and incarnates Herself as Savitri to vanquish Death.

(iv) The legend does not describe the growth of Savitri. But the epic narrates it in a Wordsworthian mode. It is said that Savitri grows imbibing the forces of Nature.

(v) The legend just mentions the meeting of Savitri and Satyavan. But the epic describes their meetings in detail for two reasons. First, it gives the poet an 
opportunity to sing the glory of love. Secondly, the poet can highlight the virtues of Satyavan. The meeting between Savitri and Satyavan is said to be the unique example of spiritual love.

(vi) In contrast to the legend, in the epic the episode of Narad's declaration of the fate of Satyavan has been raised to a very high pitch of spirituality where in cosmic purposes and intentions, the destiny of man, all are brought into play.

(vii) In the legend, the queen of Ashwapathy is merely a name. But in the epic, she is a very forceful character. She raises all those questions of life, which are usually asked by the agnostics to prove the non-existence of God. Narad patiently answers all her questions.

(viii) In the legend the conversation which takes place between Savitri and Yama is rather conventional, but in the epic, Savitri clearly stands not merely as the representative of the race but also as a representative of the Divine Mother. She defies the law of Death and defeats him with the strength of her divinity. Then Death is seen in a different form. A voice from infinity introduces him as the creator of the world and as the carrier of the seeds of thought. The whole dialogue moves on a very high plane of inspiration.

(ix) In the legend, Savitri and Satyavan, after the conquest of Death, return to the earth and Satyavan regains his father's kingdom and rules it for many years and is happy ever after with Savitri and their children. But in the poet's symbol both Savitri and Satyavan rise from the kingdom of Death to the region of the Eternal Day where the Sun of Truth never sets, where Ignorance is unknown and Death has no place. There she meets the Supreme Reality and asks for His Peace, Oneness, Energy and Joy for earthly creatures. After staying in this region of Truth for sometime, they look upon the earth and return to it in order to execute the Divine Will of raising human beings to the divine heights.

Having discussed the content of the Chitrangada and Savitri episode in both its original and re-contextualized format, let us now identify the similarities and the dissimilarities as observed in both the texts:

\section{The Comparison between Chitra and Savitri}

(i) Both the works are inspired from the Mahabharata. Chitra forms a part of the Chitrangada-Arjuna episode in the Adi Parva of the Mahabaharata whereas Savitri forms a part of the Savitri-Satyavan episode in the Vana Parva of the Mahabharata.

(ii) Both the works have been titled on the names of their heroines-Chitra and Savitri.

(iii) Both Chitra and Savitri are not puppets in the hands of the destiny. They are the creators and moulders of their own destiny.

(iv) In both the works the action takes place in the forest. (v) Both Chitra and Savitri are very unhappy and sad at the end of the year.

(vi) In both the works, the heroines pray to God (Madana and Vasanta in Chitra and Yama in Savitri).

(vii) In both the works, Time is an important factor i.e., Chitra enjoys a year's union with Arjuna and Savitri is destined to lead a happy married life for a year only.

(viii) Both the works deal with a grand subject that is philosophical in nature.

(ix) In both the works, we find 'woman in action'.

(x) Both the texts conclude that love is the main source of life, it leads to self-knowledge and immortality.

The points revolving around the names of the heroines; as moulders of their own destiny; self-knowledge all go hand-in-hand with the idea Individuality, self-hood and self-knowledge in the discourse of Women-Empowerment.

The Contrast between Chitra and Savitri:

(i) There is a difference in ideology. Chitra longs only for happiness, which is temporary while Savitri longs for wholeness, completeness and perfect-permanent union.

(ii) Chitra is a plain and an unattractive princess in man's attire whereas Savitri is a radiant, bright, calm, dignified and beautiful princess.

(iii) In Chitra, Chitra finds Arjuna and is enamoured by him. In order to marry him she requests the god of Love and the god of Spring to grant her only a day's perfect beauty. She marries him in complete knowledge about the impermanence of her relationship with Arjuna whereas in Savitri, Savitri searches out Satyavan on her own without making any request to any god. She marries him in complete knowledge about the short span of Satyavan's life.

(iv) Chitra accepts her fate whereas Savitri changes her fate with the assistance of her strong will.

(v) Both are brought up in different environments. Chitravahana brings Chitra up as a son and therefore she does not know anything about feminine delicacy and grace whereas Savitri has grown up in the lap of nature. She is wiser and much more mature than Chitra.

(vi) In the case of Chitra there is no direct divine working hand whereas a divine hand works directly in the case of Savitri.

(vii) Chitra is hasty to win the heart of Arjuna whereas Savitri takes her time and does not practice any falsehood anywhere or at anytime to win Satyavan.

(viii) Chitra wins the love of Arjuna temporarily from the gods whereas Savitri wins the love and life of Satyavan permanently from Yama.

(ix) The theme of Chitra is the evolution of human love while the theme of Savitri is the evolution of human soul.

(x) Chitra fights against Illusion whereas Savitri fights against Ignorance.

(xi) In Chitra, the chief characters are represented thus:

(a) Chitra: Human Desire for love 
(b) Arjuna: Seeker of Love

(c) Madana: god of Love

(d) Vasanta: god of Spring

In Savitri the chief characters are represented thus:

(a) Savitri: Divine Grace-Light

(b) Satyavan: Divine Truth

(c) Aswapathy: Lord of life-energy

(d) Dumathsena: Divine Mind

(e) Yama: Darkness of Ignorance

(xii) In Chitra at the end both Chitra and Arjuna part whereas in Savitri at the end both Savitri and Satyavan get united.

The points of ideological distinction, difference in upbringing in keeping with one's environment and the strong will to evolve through self-realization all go together with the principles of Women Empowerment.

\section{The Re-Contextualization of Chitra and Savitri in Terms of Women Empowerment}

\subsection{The Mahabharata Context Re-Contexualized}

Our study of Tagore's Chitra and Aurobindo's Savitri, reveals that both the texts have carved a particular niche for themselves for their thematic concerns, philosophical depth and height. Rabindranath Tagore and Aurobindo Ghose drew their inspiration from the immortal epic - the Mahabharata for their works viz., Chitra and Savitri as these heroines strike a few points of comparison with Gandhari, Kunti, Draupadi, Damyanti, Arundhati, Lopamudra, Sukanya, Odhavati and others. Both Tagore and Aurobindo are thinkers and therefore they have brought about quite a few variations in the original legends of Chitra and Savitri. Tagore and Aurobindo have chosen these stories to fulfil their aesthetic and philosophical purposes. Being good artists they know very well how to conceal their art. They do not philosophize directly but advocate a method of self-analysis in order to attain Vidya (knowledge). Chitra and Savitri are works that tell us about the greatest possibilities and purposes of human love and human life.

The impact of the Indian Renaissance, to which Tagore and Aurobindo belong, is clearly discernible in their works. Both appeared on the Indian cultural scene at a time when India was continually experiencing the colonial impact in every sphere of life. Both Tagore and Aurobindo were conscious of the colonial influence generating a habit of mind, which was ever weakening in us the apprehension of truth. In order to rebuild the nation's consciousness it was imperative for the two poets to search for legends that would sink deep into the living texture of a culture, and at the same time would have the widest extension of meaning and signification. This visionary quality of Tagore and Aurobindo created Chitra and Savitri.

Another significant aspect of Chitra and Savitri is that they are grounded in the Bengal tradition where women had been subjected to all possible social ordeals as satisystem, child marriage and the refusal to permit widowremarriage. Tagore and Aurobindo were alive to these social issues and therefore they drew in Chitra and Savitri women characters who reject these orthodox notions of the contemporary times. The two texts are a record of the progress of the society that Bengal witnessed in matters relating to the position of women in society. They succeeded in injecting the much-needed reformation in the social, cultural and religious position of the women of the times.

\subsection{Social and Spiritual Empowerment}

The aim of Tagore and Aurobindo is to attain victory over one's false-self and death, in Chitra and Savitri respectively. The outer world, the society, philosophy, science, art, music reminds them that the ultimate truth in man is in the illumination of the mind, in the extension of consciousness, in the steady evolution of the self, in the recognition of the one Truth, in the recognition for the harmony of contrary forces, in the realization that all things are spiritually one and in acquiring self-knowledge and self-transcendence. Both the artists intend to awaken the self, to raise the life and existence to a higher level of consciousness. Their works show us how an individual begins with himself, by raising his consciousness, purifying himself and realizing a wider meaning of life. They primarily aim at the unfolding of the self and the world in their works.

Both the legends of Chitra and Savitri are recreated to recover the human wholeness. They are spiritual in their theme, conception and execution. They believe in the implicit following of one's cultural heritage and familiarity with tradition. In adapting the legends of Chitra and Savitri to contemporary times, both Tagore and Aurobindo were already in an activity of tradition and cultural analysis. The mythical framework of the works highlights the Indian tradition more competently than any other text. The legends have been explored to understand the deepest mysteries of life, love and death and answer some essential existential questions. They depersonalize and become archetypes of the quest theme of the human spirit, which refuses to accept even the limitations of borrowed beauty and death. Thus, the source text - the Mahabharata, the impact of the Indian Renaissance on Tagore and Aurobindo, the grounding of the poets in the contemporary Bengal tradition, and the purpose behind the creation of these two works logically lead us to the reasons behind their choice of the two female characters - Chitra and Savitri.

\subsection{Women Empowerment: As A Symbol of Shakti-The Divine Energy}

The Indian mind is largely familiar with the idea of God in an eternal feminine aspect and therefore the Indian people have always cherished the legends of the great 
women of the ancient epics. The Chitra and Savitri legends are suggestive of the commitment that women have towards actualizing their real self and thereby fulfilling the purpose of life. Both of them symbolize the principle of Shakti, the creative power that manifests itself in order to fulfil human destiny and the cosmic design of God. Tagore and Aurobindo's quest is directed towards the realization of human unity, universal peace and happiness. Chitra and Savitri are concerned with the consciousness of men and show how they, like all other living things, grow according to their own nature. They offer to mankind the spectacle of a reawakening and rebirth of spiritual life. Chitra and Savitri extend their consciousness by their experience of life and eventually acquire self-knowledge and selftranscendence. They are educated in the self and in otherness by seeing their self, their other-half, their opposite, their false-selves and finally their whole transcendental being. In Chitra, Madana and Vasanta and in Savitri, Yoga is the means to enact the ancient story with new motifs. In both the works the action is internal, shifting back and forth on the various planes of consciousness and manifesting a spiritualized uplifting of thought, feeling and sense. The inner mind is the central point, the background of the two mighty opposites - love/beauty, reality/illusion, and love/death, knowledge/ignorance, of the two works. Both Chitra and Savitri bear witness to the conscious subjectivity of the modern mind and the expansion of the self. They meditate on the truth of life and the truth of spirit.

\subsection{Gender Equality}

Tagore was one of the earliest writers to work on the Chitra episode. The story of Chitra revolves around Chitra, a Manipuri princess, who longs to possess Arjuna at all costs. It is a powerful work on the psychological tension of a woman caught between her patience and realization of the importance of physical charm. The most dominant feature of the play, however, is the assertion of equality of women. Tagore has made Chitra an extremely poignant drama. When Arjuna develops a liking for Chitra, the huntress, Chitra expresses her knowledge of male psyche and reveals the social discrimination in our society. She asks Arjuna in sarcasm whether a woman is merely a woman when she winds herself round men's hearts with her smiles, sobs, services and caressing endearments or when a woman exhibits her learning and achievement. This question of Chitra is very significant as it throws light on our social attitudes towards women. It is taken for granted that a woman is supposed to take care of the man and her primary duty is to entertain him. A man's responsibilities as such do not ever equal that of a woman. The man may do whatever he desires to do. Neither is he supposed to take care of a woman's emotions and nor does he hold dependability in the rearing up of a child. The woman has to behave according to his whims and prejudices. But the man may behave according to his likes and dislikes. Moreover, the man has a tendency of not being very appreciative of a woman's accomplishments apart from the wealth of her physical details.

\subsection{The Female-Self: An Individual in Her Own Right}

Quintessentially, the female-self of Chitra is representative of the everyday issues of the Indian women in general. The debate of man/woman's equality would become perpetual if both were not to value each other. And Arjuna does respond positively to her queries. He does understand the need to recognize a woman's identity/individuality or else the woman would remain a mystery for the man. Chitra's and Arjuna's realization is an acknowledgement of each other's individuality. That each one of them reserves the limited space defined for her/him; that no character stands to be marginalized and that each one holds a defined center, forms the pivotal idea of Chitra. (The work also carries parallels with Kalidasa's Abhigyan Shakuntalam in terms of the character's growth, education and more importantly the attainment of Self-Knowledge).

On the other hand, Aurobindo was the first to elevate the Savitri episode to epical heights. In Savitri, the story rotates around Savitri, a Madri princess who eventually gets married to Satyavan. But he is destined to die within a year. Savitri, inspite of her mental anguish, resolutely decides to confront Death and break the cosmic law of Karma. In her quest of the Ultimate, she does not compromise with the laws of Ignorance, Darkness and Death. Rather, she successfully persuades the god of Death to give back the life of the young prince. Savitri's debate with death and her ultimate triumph over mortality have sunk deep into the soul of India. (The discussion that ensues between Savitri and Yama holds a similarity with the dialogue that takes place in the Katha Upanishad between Nachiketa and Yama).

In Chitra, Chitra had a desire in the past to fight a combat with Arjuna and defeat him in it. It obviously points to the concept of equality between man and woman. Chitra believes that both man and woman possess the same quality of intelligence and skill in every deed. And given an opportunity she is capable of proving herself in every sphere of life. Chitra consequently marks out the equality between man and woman from the physical and mental points of view. Savitri also exhibits the fact that not only holy men - rishis - can dare encounter and defy the mighty god of Death, but a woman too, armed with the qualities of Shakti (power) and Bhakti (devotion), can defeat the god of Death. Savitri conclusively indicates the equality between man and woman from the mental and spiritual points of view.

\section{Conclusion}

It is thus noted with categorical explicitness that all the principles of Women Empowerment as Strong Individuality, Equality and nondiscrimination, and the Desire for Evolution and Empowerment are all found in both Chitra and Savitri:

The points of comparison run thus: 
1. Both, Chitra and Savitri, are the only children of their parents. They carry a background story of divine birth. They do not come from conservative families but from respectable royal families which give them freedom to think, to decide and to execute deeds according to their wish and will.

2. Both Chitra and Savitri in choosing Arjuna and Satyavan repectively, go on to exhibit their feminine right, will power and confidence. Their decision to select their life partners is essentially a continuation of the tradition established by Shakuntala, Ganga, and Sharmistha.

3. Both are the recipients of Divine Grace. Chitra becomes a perfect beautiful damsel like Shruchavati and Sulabha and Savitri defeats the god of Death like Odhavati.

4. Both encounter barriers in the path of love and finally succeed in winning back their life-mates. Chitra displays growth in understanding and realization, while Savitri exhibits growth in consciousness. They realize their 'self' and embody in themselves the qualities of female psyche and unusual female achievement.

5. Both reject the two negations - the ascetic's denial of life and the sensualist's denial of the spirit.

6. Both are concerned with the welfare of humanity in general. They are not self-centered. Rather both see salvation in depersonalization. Chitra, the huntress comes to the aid of the villagers in times of distress, while Savitri dedicates herself to the cause of uplifting mankind. Both, therefore, stand as milestones in the history of women's free thinking.

7. Both exemplify and justify the meanings inherent in their names viz., Chitra - the beautiful image and Savitri - the image of the Sun god.

8. Both exemplify a life that is a synthesis of tradition and modernity. On the one hand they are fully conscious of their rights and on the other they examine their respective roles of cultural representation.

9. Both assert their individuality/ identity in relation to others. Chitra presents her true/false being only because she encounters Arjuna and Savitri transcends the physical categories of existence only because she has Satyavan living/dead by her side.

10. Both are responsible for bringing happiness/bliss to their families; they are seen as good friends of their respective life-mates; they are affectionate, intelligent, self-respected women; they are made up of a jivan shakti (life-force)/ female-consciousness that makes them distinguished; and they, as would-be mothers, are complete women.

11. Both are seekers of truth and knowledge. They successfully actualize their potential by manifesting their real self through self-upliftment. Chitra discards her borrowed beauty to face Truth as it is and Savitri defeats death by raising herself to a higher plane of consciousness.

12. Both live life as the precious gift of God. They care for the body as the temple of God and think the soul as the ultimate reality.

13. Both reflect Indian culture, Indian women and the way of living life. They assert women's valuable and meaningful place in society and public life.

14. Both exhibit the magic of Shakti (power) and the power of Prakriti (nature). They symbolize the evolution of the human love and human soul towards the Ultimate Reality.

The study reveals the following points of contrast:

1. Chitra and Savitri have a fundamental difference in terms of their familial background, social environment and mental makeup which leads to their having a different aptitude, attitude, ideology and approach to life.

2. Chitra loses her distinct personality (temporarily) for winning the love of Arjuna, while Savitri neither loses nor gives up her personality for winning the love of Satyavan.

3. Chitra struggles with her inner lower self, while Savitri struggles with the outer lower being.

4. Chitra asks for beauty for herself, while Savitri asks for life for her husband.

5. Chitra is devoid of patience, while Savitri is the very embodiment of patience.

6. Chitra's self revolves around matter, life, knowledge, bliss and consciousness, while Savitri's self revolves around matter, life, mind, knowledge, bliss, consciousness and existence.

Inspite of these few points of contrast, the two works primarily discuss female-consciousness - nari Chetna, WHICH IS A FORM OF WOMEN-EMPOWERMENT (stri-shashaktikaran) Chitra and Savitri succeed in asserting the supremacy of female discourse over male discourse. Chitra initially persuades the male gods (Madana and Vasanta) to see her point of view and then gets from them the boon desired. The boon is again a medium for Chitra to destabilize Arjuna's patriarchal position and she precisely succeeds in doing that when she observes that Arjuna cannot do without her. And then she reveals her true self. Similarly, Savitri through her dialogue with the male god of Death (Yama) subverts the traditional equations. Her victory in getting back Satyavan, is an effort to establish the superiority of female colloquy over male colloquy. The prime object of these female-centered works lies in seeing the subversion of the male-dominated society, valuing the female-self, recognizing the gender-difference and thereby discerning what may be seen as an Indian mode of feminism.

Tagore and Aurobindo as ceaseless experimenters made a quest for novelty. They tended to seek new things by adapting the old legends to present times. The women characters in the Mahabharata are powerful but none display the fearless attitude to meeting the challenges of life and death. In the entire gamut of Indian literature only 
Chitra and Savitri stand apart as the very models of female will, female psyche, female consciousness or what we call in modern times as Women Empowerment. Furthermore Tagore and Aurobindo have used Chitra and Savitri as symbols of Saundarya (beauty) and Shakti (power). They are women who can fight even against the greatest of evils - Illusion and Ignorance respectively. Their popularity in present times is an indication of the universal appeal that the works evoke irrespective of time and place. They stand as immortal characters for they are bursting with life and ceaseless vitality. Tagore and Aurobindo wanted to guide and shape the contemporary Indian sensibility. Both Chitra and Savitri guide the comtemporary women how to live life, how to be fearless and determined for self-realization.

Conclusively, the source text of Chitra and Savitri - the Mahabharata - reflects the socio-cultural, religious, political and economic conditions of the age. Chitra and Savitri are certainly the renderings of the ancient Hindu legends and bear close affinities with the mode of the Vedas and the Upanishads. The contemporary concept of ever-increasing inwardness is realized to its full potential in Chitra and Savitri. Chitra and Savitri gained fame on account of their perseverance in self-analysis and the ultimate realization of their real selves. The constant endeavour of Tagore and Aurobindo to awaken and fulfil human-hood is achieved in Chitra and Savitri. Chitra and Savitri are filled with the dharma of life-force. Thus, Tagore and Aurobindo through Chitra and Savitri display an extraordinary competence and artistic skill in arranging and molding the legends to suit their literary/social/philosophical requirements. They have a sort of secret harmony in sensing the pulse of the times. Chitra and Savitri, therefore have an inner stream of feminine power/life-force and on account of this they do not depend on the traditional roles assigned to women in India.

\section{References}

[1] Maharshi Veda Vyas, Shri Mahabharata, trans. Pandit Ramnarayan Dutt Shastry Pandeya (Gorakhpur: Geeta Press, Samvat 2045), Adhyaya: 214, Sloka: 15, p. 614.

[2] Rabindranath Tagore, Chitra (Delhi: Macmillan India, 1995), p.9.

[3] Ibid., p.32.

[4] Ibid., p. 32-33.

[5] Ibid., p. 59.

[6] Ibid., p. 66.

[7] Ibid., p. 67.

[8] Ibid., p. 28.

[9] Ibid., p. 60.

[10] Maharshi Veda Vyas, op. cit., Adhyaya: 293, Sloka: 24, p. 1773.

[11] Ibid., Adhyaya: 299, Sloka: 14, p. 1797. 